\title{
The Relationship Vitamin C Level and MMP-2 Serum with Premature Rupture of Membranes and Normal Pregnancy
}

\author{
Ika Yulia Darma, Arni Amir, Vaulinne Basyir
}

\begin{abstract}
Background: One of the important problems in obstetrics is premature rupture of membranes. Incidence of premature rupture of membranes caused by multifactorial, including the factors of infection and nutrients of pregnant women that affect the elasticity of membranes. The aim of the study to investigate the relationship vitamin C level and MMP-2 serum with premature rupture of membranes and normal pregnancy. Methods: This research is cross sectional comparative study design. The research is in the Midwife Room of Bhayangkara Hospital, dr. Reksodiwiryo and dr. Rasidin Hospital Padang in September - October 2017. The population in this study were pregnant women with early rupture of membranes and all women with normal pregnancy (gestational age $\geq 37-42$ weeks) and sample size 58 people in two groups. Sampling technique with consecutive sampling. The examination of vitamin C and MMP-2 levels was performed in Biomedical Laboratory of Faculty of Medicine, Universitas Andalas by ELISA method. Test of data normality with Shapiro-Wilk test and independent sample T test and Pearson correlation for hyphotesis. Results: The results showed that mean of vitamin $\mathrm{C}$ level in premature rupture of membranes was $0.53 \pm 0.09 \mathrm{mg} / \mathrm{dl}$, and $0.58 \pm 0.08 \mathrm{mg} / \mathrm{dl}$ in normal pregnancy $(p<0.05)$. The mean of MMP-2 level in premature rupture of membranes was $35.17 \pm 2.23 \mathrm{ng} / \mathrm{ml}$, and 33.27 \pm 0.82 $\mathrm{ng} / \mathrm{ml}$ in normal pregnancy $(\mathrm{p}<0.05)$. There was no relationship between vitamin $C$ and MMP-2 levels with premature rupture of membranes and normal pregnancy $(p>0.05)$. Conclusion: The conclusion of this study there were mean difference of vitamin $\mathrm{C}$ and MMP-2 levels in premature rupture of membranes and normal pregnancy. However, there was no relationship between vitamin $C$ and MMP-2 levels in premature rupture of membranes and normal pregnancy
\end{abstract}

Index Terms-MMP-2, premature rupture of membranes, vitamin $\mathbf{C}$.

\section{INTRODUCTION}

The World Health Organization (WHO) estimated 15\% of all pregnant women will develop into complications related to their pregnancies, and can be life-threatening to mothers and fetuses [1]. One of that important problems is premature rupture of membranes. Incidence of premature rupture of membranes estimated $8 \%$ in pregnancy. Incidence of premature rupture of membranes caused by multifactorial,

Ika Yulia Darma Master of Midwifery Program, Faculty of Medicine Universitas Andalas, Padang City, Indonesia

Arni Amir, Master of Midwifery Program, Faculty of Medicine Universitas Andalas, Padang City, Indonesia.

Vaulinne Basyir, Department of Obstetrics and Gynaecology, Dr M Djamil General Hospital, Padang City, Indonesia. including the factors of infection and nutrients of pregnant women that affect the elasticity of membranes [2].

During infection in pregnancy, the release of endocytoxins and exotoxins from microorganisms that invade chorionamnion and decidua will then activate decidua and fetal membranes to produce cytokines, in which many bioactive substances released such as prostaglandins act to stimulate uterine contractions, while on the other hand metalloproteinase affect the strength of the membrane that causes premature rupture of membranes [3,4].

Matrix metalloproteinase (MMP) is a group of proteins that break down collagen. Collagen provides primary strain strength in the fetal membrane, therefore fetal membrane is associated with increased MMP expression and activity and decreased expression activity of tissue inhibitors of matrix metalloproteinases (TIMPs). This collagen is located in the amnionic layer which is the inner layer of the fetal membrane that limits the amniotic cavity. This amnion gains its strength from collagen, especially type IV collagen, inside the basalt membrane. Matrix metalloproteinase-1 (MMP-1) degrades type I, II and III collagen, while Matrix metalloproteinase-2 (MMP-2) degrades type IV collagen [4-6].

Another cause of premature rupture of membranes is oxidative stress that occurs when prooxidants exceeds antioxidants that can cause premature rupture of membranes and is supported by one of the role of vitamin $\mathrm{C}$ to send hydrogen atoms with its single electrons to Reactive Oxygen Species (ROS) that makes collagen stronger and stable [4].

Previous study states that increasing vitamin C supplementation during pregnancy can reduce the risk of Premature Rupture of Membranes (PROM) because it is associated with oxidative stress. The amount of ascorbic acid concentration is significantly lower in the membranes of patients with PROM compared with normal pregnancies [7]. MMP2 levels increase in term delivery and there is a known increase in amnion [8]. Another study confirmed MMP2 activity increases in premature rupture of membranes $[9,10]$.

\section{MATERIALS AND METHODS}

\section{A. Study Design and Research Sample}

This research is cross sectional comparative study design. The research is in the Midwife Room of Bhayangkara Hospital, dr. Reksodiwiryo and dr. Rasidin Hospital Padang in September - October 2017. The population in this study were pregnant women with early rupture of membranes and all women with normal pregnancy (gestational age $\geq 37-42$ weeks) and sample size 58 people in two groups. Sampling 
technique with consecutive sampling.

\section{B. Operational Definitions}

The variables of this study included independent variables consisted of vitamin C (vitamin C levels in the blood) and MMP-2 level (Enzymes that degrade extracellular matrix proteins); and dependent variable: premature rupture of membranes (pregnancy with a diagnosis of premature rupture of membranes without complication and vaginal bleeding).

\section{Research Procedure}

This study was approved by the Ethical Committee of Medical Faculty, Universitas Andalas with registration number 051/KEP/FK/2017. Blood samples were drawn from all subject ( $3 \mathrm{~mL})$ and stored into EDTA containing tubes for lab transfer. Blood samples were centrifuged at $1000 \mathrm{rpm}$ for 10 min. The examination of vitamin C and MMP-2 levels was performed in Biomedical Laboratory of Faculty of Medicine, Universitas Andalas by ELISA method.

\section{Data Analysis}

Test of data normality with Shapiro-Wilk test. Bivariate analysis carried out independent sample T test and Pearson correlation. Correlation strength is stated based on the value: very weak (0.00 - 0.199), weak (0.20 - 0.399), moderate $(0.40$ - 0.599), strong (0.60 - 0.799), very strong $(0.80-1.00)$. Data-analysis was carried out in SPSS version 22.0. A two-tailed $P$-value of $<0.05$ was considered statistically significant

\section{RESULTS}

The differences of respondents characteristics in premature rupture of membranes and normal pregnancy (Table 1).

Table 1: Characteristics of Respondent in Premature Rupture of Membranes (PROM) and Normal Pregnancy

\begin{tabular}{lccc}
\hline \multicolumn{1}{c}{ Characteristics } & $\begin{array}{c}\text { PROM } \\
(\mathbf{n = 2 9})\end{array}$ & $\begin{array}{c}\text { Normal } \\
\text { Pregnancy } \\
(\mathbf{n = 2 9})\end{array}$ & $\begin{array}{c}\boldsymbol{p} \\
\text { value }\end{array}$ \\
\hline Age (years) & $27.28 \pm 3.67$ & $28.52 \pm 4.27$ & 0.240 \\
Gestational age & $36.29 \pm 4.44$ & $38.87 \pm 1.01$ & 0.005 \\
(weeks) & $22.70 \pm 1.16$ & $23.00 \pm 1.00$ & 0.300 \\
Body mass index & $116.21 \pm$ & $113.45 \pm$ & 0.238 \\
Systolic blood & 9.03 & 8.57 & \\
pressure (mmHg) & & & 0.014 \\
$\begin{array}{l}\text { Diastolic blood } \\
\text { pressure (mmHg) }\end{array}$ & $73.45 \pm 7.69$ & $68.79 \pm 6.22$ & \\
\hline
\end{tabular}

Table 1 known that there is no difference age, gestational age, body mass index, systolic blood pressure, diastolic blood pressure in patients with premature rupture of membranes and normal pregnancy $(\mathrm{p}>0.05)$.

The mean difference vitamin $\mathrm{C}$ level with premature rupture of membranes and normal pregnancy (Table 2).
Table 2. The mean difference vitamin $\mathrm{C}$ level with premature rupture of membranes and normal pregnancy

\begin{tabular}{lccc}
\hline & \multicolumn{2}{c}{ Groups } & \\
\cline { 2 - 3 } Variable & $\begin{array}{c}\text { PROM } \\
(\text { Mean } \pm \text { SD) }\end{array}$ & $\begin{array}{c}\text { Normal } \\
\text { Pregnancy } \\
(\text { Mean } \pm \text { SD) }\end{array}$ & P value \\
\hline $\begin{array}{l}\text { Vitamin C } \\
\text { level }(\mathrm{mg} / \mathrm{dl})\end{array}$ & $0.53 \pm 0.09$ & $0.58 \pm 0.08$ & 0.018 \\
\hline
\end{tabular}

Table 2 known mean of vitamin $\mathrm{C}$ level in premature rupture of membranes were $0.53 \pm 0.09 \mathrm{mg} / \mathrm{dl}$, while the mean vitamin $\mathrm{C}$ level in normal pregnancy were $0.58 \pm 0.08$ $\mathrm{mg} / \mathrm{dl}$. The results of the statistical tests with independent $\mathrm{T}$ test $p=0.018(p<0.05)$ it can be concluded that there are mean differences vitamin $\mathrm{C}$ level in premature rupture of membranes and normal pregnancy.

The mean difference MMP-2 level with premature rupture of membranes and normal pregnancy (Table 3).

Table 3. The mean difference MMP-2 level with premature rupture of membranes and normal pregnancy

\begin{tabular}{cccc}
\hline & \multicolumn{2}{c}{ Groups } & \\
\cline { 2 - 3 } Variable & $\begin{array}{c}\text { PROM } \\
(\text { Mean } \pm \text { SD) }\end{array}$ & $\begin{array}{c}\text { Normal } \\
\text { Pregnancy } \\
\text { (Mean } \pm \text { SD) }\end{array}$ & P value \\
\hline $\begin{array}{l}\text { MMP-2 level } \\
(\mathrm{ng} / \mathrm{ml})\end{array}$ & $35.17 \pm 2.23$ & $33.27 \pm 0.82$ & 0.000 \\
\hline
\end{tabular}

Table 3 known mean of MMP-2 levels in premature rupture of membranes were $35.17 \pm 2.23 \mathrm{ng} / \mathrm{ml}$, while the mean MMP-2 levels in normal pregnancy were 33.27 \pm 0.82 $\mathrm{ng} / \mathrm{ml}$. The results of the statistical tests with independent $\mathrm{T}$ test $p=0,000(p<0.05)$ it can be concluded that there are mean differences MMP-2 level in premature rupture of membranes and normal pregnancy.

Relationship of vitamin C levels and MMP-2 Serum with premature rupture of membranes (Figure 1,2).

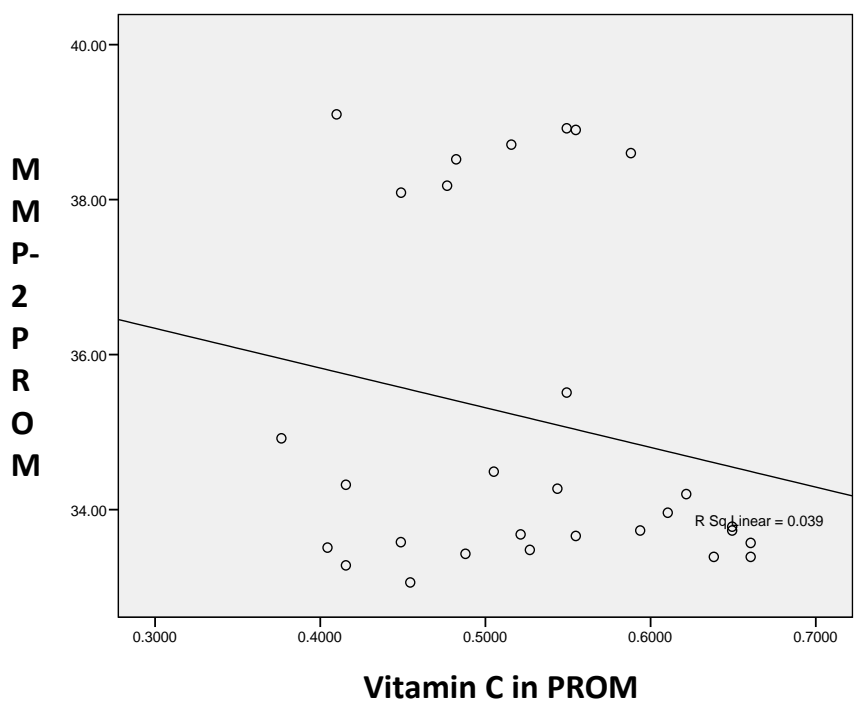

Figure 1. The Relationship Vitamin C Level and MMP-2 Serum with Premature Rupture of Membranes 


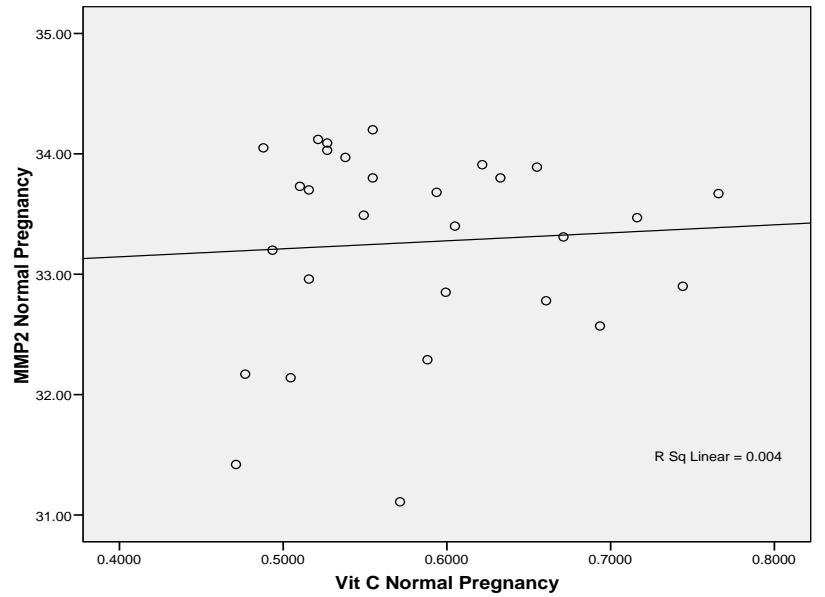

Figure 2. The Relationship Vitamin C Level and MMP-2 Serum with Normal Pregnancy

Correlation of vitamin C and MMP-2 levels in premature rupture of membranes and normal pregnancy have a negative correlation, that's meaning that if there is an increase in vitamin $\mathrm{C}$ levels, there will be a decrease in MMP-2 levels. Based on the results of the Pearson correlation statistical test it is known that there is no correlation between vitamin $\mathrm{C}$ and MMP-2 levels with premature rupture of membranes and normal pregnancy $(\mathrm{p}>0.05)$.

\section{DISCUSSION}

The results showed that mean of vitamin $\mathrm{C}$ level in premature rupture of membranes was $0.53 \pm 0.09 \mathrm{mg} / \mathrm{dl}$, and $0.58 \pm 0.08 \mathrm{mg} / \mathrm{dl}$ in normal pregnancy $(\mathrm{p}<0.05)$. The mean of MMP-2 level in premature rupture of membranes was $35.17 \pm 2.23 \mathrm{ng} / \mathrm{ml}$, and $33.27 \pm 0.82 \mathrm{ng} / \mathrm{ml}$ in normal pregnancy $(\mathrm{p}<0.05)$. There was no relationship between vitamin $\mathrm{C}$ and MMP-2 levels with premature rupture of membranes and normal pregnancy $(\mathrm{p}>0.05)$.

Previous study states that increasing vitamin $\mathrm{C}$ supplementation during pregnancy can reduce the risk of Premature Rupture of Membranes (PROM) because it is associated with oxidative stress. The amount of ascorbic acid concentration is significantly lower in the membranes of patients with PROM compared with normal pregnancies [7]. MMP2 levels increase in term delivery and there is a known increase in amnion [8]. Another study confirmed MMP2 activity increases in premature rupture of membranes [9, 10]. Vitamin C /ascorbic acid affects matrix metalloproteinase 2 (MMP-2) expression [11].

Based on the analysis of the researchers there was no correlation between vitamin C and MMP-2 levels with premature rupture of membranes in this study because the researchers only looked at vitamin C and MMP-2 levels for one time, where the researchers did not see the size of respondents' vitamin $\mathrm{C}$ intake during pregnancy or not know the nutritional adequacy of vitamin $\mathrm{C}$ for pregnant women, this condition causes no visible role for vitamin $\mathrm{C}$ in reducing serum MMP-2 levels and preventing premature rupture of membranes.

The main mechanism of the occurrence of amniotic membrane weakening is the collagen metabolism disorder because it is the development of mechanical integrity in the amniotic membrane and tissue stress factor. Vitamin $\mathrm{C}$ is involved in the maintenance of collagen synthesis, collagen secretion, collagenolysis, and antioxidants that inhibit the effects of damage from oxidative stress [12].

Vitamin $\mathrm{C}$ or ascorbic acid is one of the important antioxidants that dissolve in water in this case in the body is plasma. Vitamin $\mathrm{C}$ acts as a reducing agent by sending one atom of hydrogen with one electron to ROS, which initially has an unpaired electron in the presence of the ascorbic elektorn acid in pairs, so as to stabilize, and cause ROS weakening [12,13].

Ascorbic acid is involved in several biochemical stages of synthesis and collagen protection. Ascorbic acid stimulates fibroblasts to synergize collagen pro and acts as a co-factor to strengthen collagen by promoting the formation of hydroxyproline linkages in triple helix. This is what protects collagen by forming TIMPs and causes a decrease in MMP-2 thus preventing the degradation of the membranes of membranes by ROS. Clinically, low plasma vitamin C concentrations were associated with an increased risk of premature rupture of membranes [14,15].

\section{CONCLUSION}

The conclusion of this study there were difference of mean of vitamin C and MMP-2 levels in premature rupture of membranes and normal pregnancy. However, there was no association between vitamin C and MMP-2 levels in premature rupture of membranes and normal pregnancy. This study suggests that serum vitamin $\mathrm{C}$ and serum MMP-2 levels may be used as parameters to help diagnostic premature rupture of membranes, increased intake of vitamin $C$ through vitamin $\mathrm{C}$ supplementation in pregnant women to prevent the risk of premature rupture of membranes and cohort study or experiment study to see the effect of vitamin $\mathrm{C}$ supplementation and MMP-2 levels to see the incidence of premature rupture of membranes.

\section{ACKNOWLEDGMENT}

The authors would like to thank Ricvan Dana Nindrea, MPH for data analysis and Mac Arif Hamdanas, MA for translating.

\section{REFERENCES}

[1] World Health Organization. Nutrition and pregnancy [cited 2018 May 29] from: http://www.who.int/nutrition/publications/pregnant/en/

[2] Popowski T, Goffinet F, Maillard F, Schmitz T, Leroy S, Kayem G Maternal markers for detedting early onset neonatal infection and chorioamnionitis in cases of prematur rupture of membranans at or after 34 weeks of gestation: a two center prospective study. Biomedcentral Journal 2011; 11(26):1-9.

[3] Alriyami N, Al-Ruheili I, Al-Shezaw F, Al-Khabori M. Extreme Preterm Premature Rupture of Membranes: Risk Factors and Feto Maternal Outcomes. Oman Med J. 2013; 28(2): 108-111.

[4] Tejero E, Perichart O, Pfeffer F, Casanueva E, Vadillo-Ortega F. Collagen synthesis during pregnancy, vitamin $\mathrm{C}$ availability, and risk of premature rupture of fetal membranes. Int J Gynaecol Obstet 2003; 81(1):29-34. 
[5] Parry S, Strauss JF. Mechanism of disease premature rupture of membranes. N Engl J Med 1998; 338, 663-70.

[6] Xu P, Alfaidly N, Challis JR. Expression of matrix metalloproteinase (MMP)-2 and MMP-9 in human placenta and fetal membranes in relation to preterm and term labor. J Clin Endocrinol Metab 2002; 87(3):1353-61

[7] Richa S, Sumita M. Ascorbic acid concentration and preterm premature rupture of membranes. The Journal of Obstetrics and Gynecology of India 2014; 64(6):417-420.

[8] Yoneomoto H, Young CB, Ross JT, Guilbert LL, Fairclough RJ, Olson DM. Changes in matrix metalloproteinase (MMP)-2 and MMP-9 in the fetal amnion and chorion during gestation and at term and preterm labor. Placenta 2006; 27(6-7):669-77.

[9] Ota A, Yonemoto H, Someya A, Itoh S, Kinoshita K. Changes in matrix metalloproteinase 2 activities in amniochorions during premature rupture of membranes. Sage Journals 2006; 13(8): 592-597.

[10] Vincent ZL, Mitchell MD, Ponnampalam AP. Regulation of MT1-MMP/MMP-2/TIMP-2 axis in human placenta. J Inflamm Res 2015; 8:193-200.

[11] Spinatto J, Freire S, Silva J, Rudge M, Martins-Costa S, Koch M. Antioxidant supplementation and premature rupture of the membranes: a planned secondary analysis. Am J Obstet Gynecol 2008; 199(4): 433.e1-433.e8.

[12] Gopalani S, Krohn M, Meyn L, Hitti J, Crombleholme W. Contemporary management of preterm premature rupture of membranes: determinants of latency and neonatal outcome. Am J Perinatol 2004; 21(4): 183-90.

[13] Woods, JR. Pathobiology; oxidant stress, angiogenesis and neoplasia. Placenta 2001; 15: S38-S44.

[14] Pfeffer F, Casanueva E, Kamar J, Guerra A, Perichart D, Vadillo-Ortega F. Modulation of 72-kiloclalton type IV collagenase (matriz metalloproteinase-2) by ascorbic acid in cultured human amnion-derived cells. Biol Reprod 1998; 59: 326-329.

[15] Hamilton IM, Gilmore WAS, Benzie IF, Mulholland CW, Strain JJ. Interactions between vitamin $\mathrm{C}$ and $\mathrm{E}$ in human subjects. Br J Nutr 2000; 84: 261-267.

Ika Yulia Darma Master of Midwifery Program, Faculty of Medicine Universitas Andalas, Padang City, Indonesia, (e-mail: ikayulia@ gmail.com). Arni Amir, Master of Midwifery Program, Faculty of Medicine Universitas Andalas, Padang City, Indonesia.

Vaulinne Basyir, Department of Obstetrics and Gynaecology, Dr M Djamil General Hospital, Padang City, Indonesia. 